BBA 77342

\title{
AMINO ACID STIMULATION OF ATP CLEAVAGE BY TWO EHRLICH CELL MEMBRANE PREPARATIONS IN THE PRESENCE OF OUABAIN
}

\author{
WHA BIN IM, HALVOR N. CHRISTENSEN and BERNARD SPORTÉS \\ Department of Biological Chemistry, The University of Michigan, Ann Arbor, Mich. 48109 (U.S.A.)
}

(Received December 24th, 1975)

SUMMARY

Two membrane fractions prepared from the Ehrlich ascites-tumor cell show non-identical stimulatory responses to certain amino acids in their $\mathrm{Mg}^{2+}$-dependent activity to cleave ATP, despite the presence of ouabain and the absence of $\mathrm{Na}^{+}$or $\mathrm{K}^{+}$. The first of these, previously described, shows little $\left(\mathrm{Na}^{+}+\mathrm{K}^{+}\right)$-ATPase activity, and is characteristically stimulated by the presence of certain diamino acids with low $\mathrm{p} K_{2}$, and at $\mathrm{pH}$ values suggesting that the cationic forms of these amino acids are effective. The evidence indicates that these effects are not obtained through occupation of the kinetically discernible receptor site serving characteristically for the uphill transport of these amino acids into the Ehrlich cell. The second membrane preparation was purified with the goal of concentrating the $\left(\mathrm{Na}^{+}+\mathrm{K}^{+}\right)$-ATPase activity. It also is stimulated by the model diamino acid, 4-amino-1-methylpiperidine-4carboxylic acid, and several ordinary amino acids. The diamino acids were most effective at $\mathrm{pH}$ values where the neutral zwitterionic forms might be responsible. Among the optically active amino acids tested, the effects of ornithine and leucine were substantially stronger for the $\mathrm{L}$ than for the $\mathrm{D}$ isomers. The list of stimulatory amino acids again corresponds poorly to any single transport system, although the possibility was not excluded that stimulation might occur for both preparations by occupation of a membrane site which ordinarily is kinetically silent in the transport sequence. The high sensitivity to deoxycholate and to dicyclohexylcarbodiimide of the hydrolytic activity produced by the presence of L-ornithine and 4-amino-1-methylpiperidine-4-carboxylic acid suggests that the stimulatory effect is not merely a general intensification of the background $\mathrm{Mg}^{+}$-dependent hydrolytic activity.

\section{INTRODUCTION}

Objections have been raised to ascribing the full energization of amino acid uptake by cells to co-transport with $\mathrm{Na}^{+}$and countertransport with intracellular amino acids. An alternative or additional energizing role for the catalytic hydrolysis of

Abbreviations: HEPES, $N$-2-hydroxyethylpiperazine- $N$ '-2-ethanesulfonic acid; DCCD, dicyclohexylcarbodiimide. 
ATP has been suspected but not proved. Several reports indicate that the $\left(\mathrm{Na}^{+}+\mathrm{K}^{+}\right)$ATPase of various animal cells can be stimulated by the presence of amino acids $[1,2,3]$. The significance of these observations has, however, not been entirely clear, because the stimulatory effect might be attributed to the chelating activity of the effective amino acids for divalent cations, e.g. $\mathrm{Ca}^{2+}$, rather than to direct interaction between the amino acids and the ATPase. Such divalent cations are known to be inhibitors of the enzyme system. Recently Forte et al. [4] showed with a plasma membrane fraction from the Ehrlich cell that stimulations of $\left(\mathrm{Na}^{+}+\mathrm{K}^{+}\right)$-ATPase activity by various amino acids are still manifest in the presence of ethylenediamine tetraacetic acid. The amino acid stimulation was found, however, to be specific neither to the $\mathrm{L}$ isomers nor to the substrates of any known transport system.

In contrast to the $\left(\mathrm{Na}^{+}+\mathrm{K}^{+}\right)$-ATPase, the basal $\mathrm{Mg}^{2+}$-requiring and ouabaininsensitive ATP-hydrolyzing activity of plasma membrane has not been examined well for its possible role in transport of amino acids. Recently Ronquist and Christensen [5] observed in this laboratory a stimulatory effect of certain diamino acids on the ouabain-insensitive ATP-splitting activity of membraneous vesicles isolated from the Ehrlich cell. Association of this activity with the function of plasma membrane was equivocal, however, because the usual marker for the plasma membrane, the $\left(\mathrm{Na}^{+}+\mathrm{K}^{+}\right)$-ATPase activity, was virtually absent from this membrane preparation. In the present research we have reexamined this effect, and also studied the effect of various amino acids on the ouabain-insensitive ATP-hydrolyzing activity of a different membrane preparation separated so as to concentrate the $\left(\mathrm{Na}^{+}+\mathrm{K}^{+}\right)$-ATPase activity, and therefore considered to be plasma membrane.

\section{MATERIALS}

$\left[\gamma^{32} \mathrm{P}\right]-A T P$ was prepared according to the method of Glynn and Chappell [6]. di $\mathrm{Na}^{2+}$-ATP and Tris/ATP were purchased from Sigma. 3-phosphoglyceraldehyde dehydrogenase and 3-phosphoglycerate kinase were obtained from BoehringerMannheim $\mathrm{GmbH}$. All other materials were of reagent grade quality and obtained from standard sources.

\section{METHODS}

\section{Preparation of membrane fractions}

The first membrane preparation used was separated as described previously [5]. The second membrane preparation, plasma membrane marked with the $\left(\mathrm{Na}^{+}+\right.$ $\mathrm{K}^{+}$)-ATPase, was isolated as described below. Typically, this second membrane fraction was prepared from Ehrlich ascites tumor cells collected from 8 mice which had been inoculated with the tumor 8 days earlier. We followed the method of Forte et al. [4] with the following modifications. Cells first washed in $0.9 \% \mathrm{NaCl}$ were resuspended in 6 vol. of cold homogenizing medium containing $15 \mathrm{mM}$ sodium phosphate ( $\mathrm{pH} 7.4$ ), $1 \mathrm{mM} \mathrm{Mg}^{2+}$ and $10 \mathrm{mM} \mathrm{NaCl}$, instead of $18 \mathrm{mM}$ Tris ( $\mathrm{pH} 8.0$ ), $0.5 \mathrm{mM} \mathrm{Ca}^{2+}$ and $25 \mathrm{mM} \mathrm{NaCl}$. After rupture of the cells with a Dounce homogenizer, using a tight pestle, the homogenates were fractionated by differential centrifugation as shown in Scheme 1. Analysis of $\left(\mathrm{Na}^{+}+\mathrm{K}^{+}\right)$-ATPase activities of the various fractions (refer to Table I) revealed that Fraction 1, initially sedimented to 


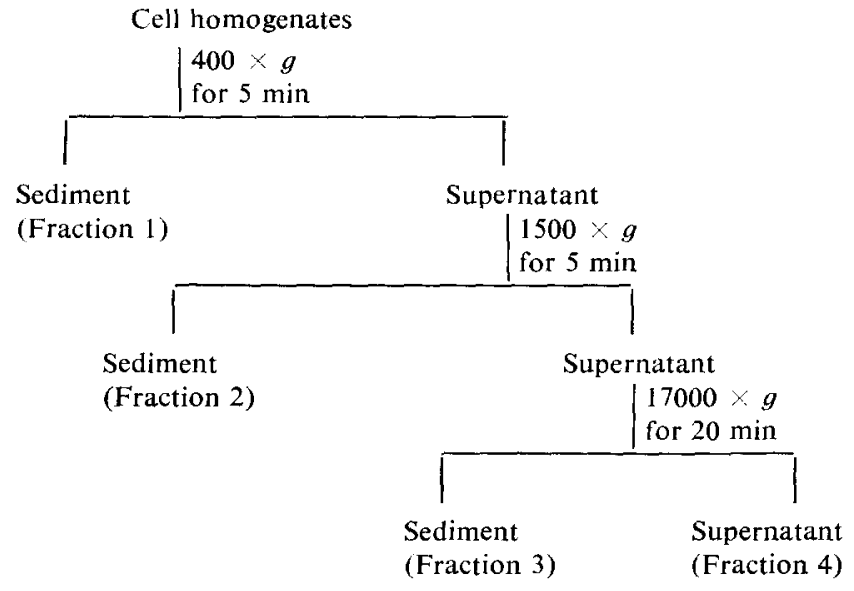

form a pellet from the homogenates by centrifugal force $400 \times g$ for $5 \mathrm{~min}$, contained most of $\left(\mathrm{Na}^{+}+\mathrm{K}^{+}\right)$-ATPase activity of the homogenates. Hence this fraction was subjected to the following purification procedures. It was suspended in 3 vol. of 7.5 $\mathrm{mM}$ sodium phosphate (pH 7.4), containing $5 \mathrm{mM} \mathrm{Mg}^{2+}, 5 \mathrm{mM} \mathrm{NaCl}$ and $18 \%$ glycerol $(\mathrm{v} / \mathrm{v})$. The suspension was briefly incubated at $37^{\circ} \mathrm{C}$. Heavy aggregates forming at high concentrations of $\mathrm{Mg}^{2+}$ were removed by filtration through two layers of cheese-cloth. The filtrates were centrifuged at $1000 \times g$ for $5 \mathrm{~min}$. The pellet obtained from the filtrates by centrifugation was suspended in 4 vol. of the homogenizing medium. The suspension was passed under high manual pressure 5 times through a No. 27 gauge needle. An aliquot of $7 \mathrm{ml}$ of the suspension was layered over a step gradient, consisting of successive $6-\mathrm{ml}$ layers of $50,60,67,74$ and $83 \%$ glycerol $(\mathrm{v} / \mathrm{v})$ in a Spinco SW27 rotor tube. Ultracentrifugation was at $25000 \mathrm{rev} / \mathrm{min}$ for $1 \mathrm{~h}$. The 60-67\% interfacial fraction (Band 3) was collected, diluted with a $15 \mathrm{mM}$ sodium phosphate solution ( $\mathrm{pH} 7.4$ ) containing $10 \mathrm{mM} \mathrm{NaCl}$, and sedimented to form a pellet. The pellet was resuspended in $15 \mathrm{mM}$ solution of sodium phosphate ( $\mathrm{pH} \mathrm{7.4)}$ containing $0.25 \mathrm{M}$ glycerol to give a final protein concentration of $0.3-0.5 \mathrm{mg} / \mathrm{ml}$. This suspension was frozen in an acetone/solid $\mathrm{CO}_{2}$ mixture and stored at $-70^{\circ} \mathrm{C}$. Like the first preparation, it has a vesicular appearance by electron microscopy, in the present case resembling the micrograph published by Forte et al. [4]. For comparison, a corresponding preparation of plasma membrane was made in Tris buffer ( $\mathrm{pH} 8.0$ ). In this case, $15 \mathrm{mM}$ sodium phosphate $(\mathrm{pH} 7.4$ ) was replaced with $18 \mathrm{mM}$ Tris ( $\mathrm{pH} \mathrm{8.0)}$ in all the solutions.

\section{Assay of ATPase activity}

For an independent verification of the amino-acid stimulated ATPase action of the membrane preparation of Ronquist and Christensen [5], the chemical method for inorganic orthophosphate ion developed by Lindberg and coworkers [7-11] was applied, the trichloroacetic-acid-treated, centrifuged assay sample being first reacted with $0.3 \mathrm{M}$ sodium iodoacetate to destroy the interfering mercaptoethanol. The assay for amino-acid-stimulated ATPase was otherwise carried out as previously described [5], but using a $N$-2-hydroxyethylpiperazine- $N^{\prime}$-2-ethanesulfonic acid (HEPES) 
rather than a Tris buffer, and allowing $10 \mathrm{~min}$ at $37^{\circ} \mathrm{C}$ for hydrolysis. The sedimented protein was in all cases measured by the method of Lowry et al. [12].

For measurement of ATP-hydrolysis by determining of ${ }^{32} \mathbf{P}$ the regular assay medium contained $15 \mathrm{mM}$ sodium phosphate, $\mathrm{pH} 7.4$, unless otherwise stated, $4 \mathrm{mM}$ $\mathrm{MgCl}_{2}, 0.25 \mathrm{M}$ glycerol, $0.10-0.17 \mathrm{mg}$ of protein $/ \mathrm{ml}$ and other ingredients as described below, in a final volume of $2.9 \mathrm{ml}$. To measure the ouabain-insensitive ATP cleavage, $1 \mathrm{mM}$ ouabain was included. For $\left(\mathrm{Na}^{+}+\mathrm{K}^{+}\right)$-ATPase activity, $100 \mathrm{mM} \mathrm{NaCl}$ and $15 \mathrm{mM} \mathrm{KCl}$ were added to two portions of the above medium, only one of which was supplemented with ouabain. Amino acids were sometimes included as indicated in the figures. The suspension was usually subjected to a preliminary incubation for $20 \mathrm{~min}$ at $37^{\circ} \mathrm{C}$, except for those studies designed to examine time parameters. Then the reaction was initiated by adding $0.1 \mathrm{ml}$ of a solution containing $12 \mu \mathrm{mol}\left[\gamma_{-}{ }^{32} \mathrm{P}\right]-$ AT'P-Na salt in $15 \mathrm{mM}$ sodium phosphate, $\mathrm{pH} 7.4$. At the incubation time of $30 \mathrm{~min}$, unless otherwise indicated, the reaction was terminated by adding $4 \mathrm{ml}$ ice-cold $10 \%$ trichloroacetic acid solution. Liberated ${ }^{32} \mathrm{P}$ was measured according to Blostein [13]. In the experiment designed to study the effect of using a Tris buffer, sodium phosphate was replaced with $15 \mathrm{mM}$ Tris, pH 8.0. In this case $\left[\gamma-{ }^{32} \mathrm{P}\right] \mathrm{ATP}$ was used as its Tris salt. The Tris standard medium carried $10 \mathrm{mM}$ mercaptoethanol [5] in addition to the ingredients described before. Protein was determined according to the method of Lowry et al. [12].

\section{RESULTS}

\section{Purification of membrane fractions}

The course of the differential sedimentation leading to the second preparation is indicated in Table $I$, Scheme 1 , which shows the ATP-splitting activity of various fractions. Fraction 2, sedimented to form a pellet at $1500 \times g$ for $5 \mathrm{~min}$, shows the highest specific activity of $\left(\mathrm{Na}^{+}+\mathrm{K}^{+}\right)$-ATPase. The total activity of the enzyme associated with Fraction 2 is only $15 \%$ of that of homogenates, however, whereas Fraction 1 contains most of the enzyme activity of homogenates $(95 \%)$. The relatively low gravitational force $(400 \times g$ for $5 \mathrm{~min}$ ) used to obtain Fraction 1 indicates that the plasma membrane fraction produced by this method consists primarily of large fragments and ghosts. Fraction 3, sedimented to form a pellet at $17000 \times g$ for $20 \mathrm{~min}$, shows very little $\left(\mathrm{Na}^{+}+\mathrm{K}^{+}\right)$-ATPase activity. On the other hand, the highest specific activity of ouabain-insensitive ATPase was found in Fraction 3, indicating that mitochondria are the major component of this fraction.

Table II records the stepwise purification used for plasma membrane from Fraction 1. High divalent cation levels are known to promote aggregation of intracellular organelles, especially nuclei [15]. As expected, treatment of Fraction 1 with $5 \mathrm{mM} \mathrm{Mg}^{2+}$ caused formation of heavy aggregates. Approximately 5-fold concentration of $\left(\mathrm{Na}^{+}+\mathrm{K}^{+}\right)$-ATPase activity was achieved by filtering off and eliminating the aggregates. Passage of the filtrates through the No. 27-gauge needle served to fragment large vesicles of plasma membrane to smaller ones, thereby freeing cytoplasmic components trapped within the large vesicles.

From the glycerol density gradient, the major interfacial band (Band 3) between 60 and $67 \%$ glycerol was found to contain almost $60 \%$ of the $\left(\mathrm{Na}^{+}+\mathrm{K}^{+}\right)$ATPase activity applied initially. A considerable amount of particulate material had 
sedimented to the bottom of the centrifuge tube. Among several minor bands, Band 4 (67-74\% glycerol) was noted to carry relatively high $\left(\mathrm{Na}^{+}+\mathrm{K}^{+}\right)$-ATPase activity. This band differs, however, from Band 3 in its ouabain-insensitive ATP-hydrolyzing activity, approximately $50 \%$ higher than that of Band 3 in this experiment. When

\section{TABLE I}

DISTRIBUTION OF $\left(\mathrm{Na}^{+}+\mathrm{K}^{+}\right)$-ATPaSe AND THE OUABAIN-INSENSITIVE ATP-HYDROLYZING ACTIVITY IN THE VARIOUS FRACTIONS OBTAINED BY DIFFERENTIAL CENTRIFUGATION

Incubation was in $15 \mathrm{mM}$ sodium phosphate buffer $(\mathrm{pH} 7.4)$ at $37^{\circ} \mathrm{C}$. See Methods for details. Ascites cells were collected from 4 mice.

\begin{tabular}{|c|c|c|c|c|c|}
\hline \multirow[t]{2}{*}{ Fraction } & \multirow[t]{2}{*}{$\begin{array}{l}\text { Protein } \\
(\mathrm{mg})\end{array}$} & \multicolumn{2}{|c|}{$\begin{array}{l}\text { Specific activities }\left(\mu \mathrm{mol} \mathbf{P}_{1} / \mathrm{h} / \mathrm{mg}\right. \\
\text { of protein) }\end{array}$} & \multirow{2}{*}{$\begin{array}{l}\text { Total activ- } \\
\text { ity of }\left(\mathrm{Na}^{+}\right. \\
\left.+\mathrm{K}^{+}\right)- \\
\text {ATPase } \\
(\mu \mathrm{mol})\end{array}$} & \multirow{2}{*}{$\begin{array}{l}\text { Recovery } \\
\text { of }\left(\mathrm{Na}^{+}\right. \\
\left.\cdots \mathrm{K}^{+}\right)- \\
\text {ATPase } \\
\text { activity } \\
(\%)\end{array}$} \\
\hline & & $\begin{array}{l}\text { Ouabain-insensi- } \\
\text { tive ATP- } \\
\text { hydrolysis }\end{array}$ & $\begin{array}{l}\left(\mathrm{Na}^{+}+\mathrm{K}^{+}\right)- \\
\text {ATPase }\end{array}$ & & \\
\hline Homogenates & 1141 & 0.70 & 0.31 & 353 & 100 \\
\hline $\begin{array}{l}\text { Fraction } 1 \\
\qquad(400 \times g \text { for } 5 \mathrm{~min})\end{array}$ & 286 & 1.32 & 1.18 & 337 & 95 \\
\hline $\begin{array}{l}\text { Fraction } 2 \\
\qquad(1500 \times g \text { for } 5 \mathrm{~min})\end{array}$ & 26 & 1.44 & 2.09 & 54 & 15 \\
\hline $\begin{array}{l}\text { Fraction } 3 \\
\qquad(17000 \times g \text { for } 20 \mathrm{~min})\end{array}$ & 164 & 3.13 & 0.38 & 62 & 17 \\
\hline $\begin{array}{l}\text { Fraction } 4 \\
\quad \text { (Soluble supernatant) }\end{array}$ & 506 & 0.27 & 0.02 & 10 & 3 \\
\hline
\end{tabular}

\section{TABLE II}

\section{COURSE OF THE PREPARATION OF PLASMA MEMBRANE FROM FRACTION 1}

The degree of purification for plasma membrane at each step was estimated from the specific activity of $\left(\mathrm{Na}^{+}+\mathrm{K}^{+}\right)$-ATPase. Note that the stimulation by L-ornithine represents the increment of the ouabain-insensitive ATP-hydrolysis by the plasma membrane fraction due to the addition of $16 \mathrm{mM}$ of the amino acid. See Methods for details.

\begin{tabular}{|c|c|c|c|c|}
\hline \multirow[t]{2}{*}{ Fraction } & \multirow{2}{*}{$\begin{array}{l}\text { Protein } \\
(\mathrm{mg})\end{array}$} & \multicolumn{3}{|c|}{ Specific activities ( $\mu \mathrm{mol}$ of $\mathrm{P}_{1} / \mathrm{h} / \mathrm{mg}$ of protein) } \\
\hline & & $\begin{array}{l}\text { Ouabain- } \\
\text { insensitive } \\
\text { ATP-hydrolysis }\end{array}$ & $\begin{array}{l}\left(\mathrm{Na}^{+}+\mathrm{K}^{+}\right)- \\
\text {ATPase }\end{array}$ & $\begin{array}{l}\text { Stimulation by } \\
\text { L-ornithine }\end{array}$ \\
\hline Fraction 1 & 286 & 1.32 & 1.18 & 0.20 \\
\hline $\begin{array}{l}\text { Filtrates after } \\
\quad 5 \mathrm{mM} \mathrm{Mg}^{2+} \text { treatment }\end{array}$ & 40 & 4.33 & 5.49 & 0.62 \\
\hline $\begin{array}{l}\text { Band } 3(60-67 \%) \text { from } \\
\text { glycerol density } \\
\text { gradient }\end{array}$ & 13.3 & 3.92 & 9.58 & 1.52 \\
\hline $\begin{array}{l}\text { Band } 4(67-74 \%) \text { from } \\
\text { glycerol density } \\
\text { gradient }\end{array}$ & 3.1 & 5.52 & 8.39 & 1.23 \\
\hline
\end{tabular}


Band 4 was further fragmented and recentrifuged under the same conditions, a considerable portion was located at the interface of 60-67\% glycerol gradient. This result was interpreted to mean that Band 4 is somewhat less homogeneous plasma membrane fraction than Band 3. When the isolation procedures were carried out using Tris buffer instead of sodium phosphate, Band 3 became less conspicuous but still appeared to be a major fraction. No significant change was observed in the ATPase activity of Band 3 isolated using Tris buffer.

\section{Further description of effects of amino acids on the ouabain-insensitive ATPase activity}

First preparation. The stimulating action of the diamino acid analog with low $\mathrm{p} K_{\mathrm{a} 2}$, 4-amino-1-methylpiperidine-4-carboxylic acid [14] on ATP cleavage by the first membrane preparation as described by Ronquist and Christensen [5] was verified more than 50 times during the present study, and that by the analogs azaleucine ( $\beta$-dimethylamino-L-alanine) and thialysine ( $S$-aminoethyl-L-cysteine) repeatedly in the hands of B.S. Ornithine stimulation was again equivocal, and neutral amino acids were without effect at $10 \mathrm{mM}$. The same amount of phosphate was found released from $\left[\gamma^{32} \mathrm{P}\right] \mathrm{ATP}$ under the stimulation of the first-named analog, whether measured radioactively by release of ${ }^{32} \mathrm{P}_{i}$, or by chemical measurement of orthophosphate ion. These experiments were made in $25 \mathrm{mM}$ HEPES buffer, $\mathrm{pH} 6.0$. Therefore we may conclude that the cleavage releases only the terminal phosphoryl group from ATP. Other properties of the stimulated cleavage corresponded to those described previously [5].

Selected amino acids which are themselves not stimulatory ought to block the stimulating action of the effective diamino acids if that action takes place through occupation of a site characteristically occupied during transport of the presumed inhibitor. Fig. I illustrates that the stimulating action of azaleucine is not significantly decreased by the presence of lysine or 2-aminonorbornane-2-carboxylic acid, charac-

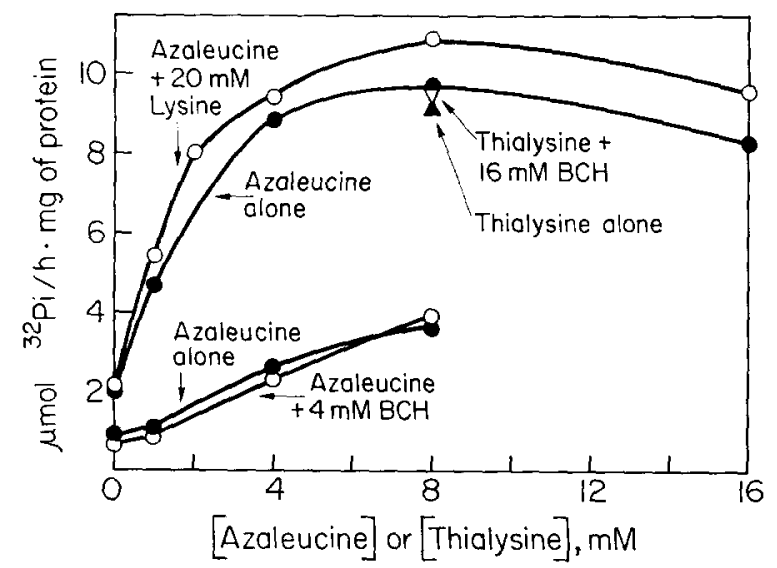

Fig. 1. Failure of substrates of System $L y^{+}$(lysine) or System $L$ (2-amino-norbornane-2-carboxylic acid) to block the stimulatory effect of azaleucine on ATP splitting in the presence of ouabain, 0.5 $\mathrm{mM}$, in the first membrane preparation. BCH, 2-aminonorbornane-2-carboxylic acid. HEPES buffer, pH 6.0, was used. The stimulating action was atypically weak in the experiment described by the lower pair of curves. 


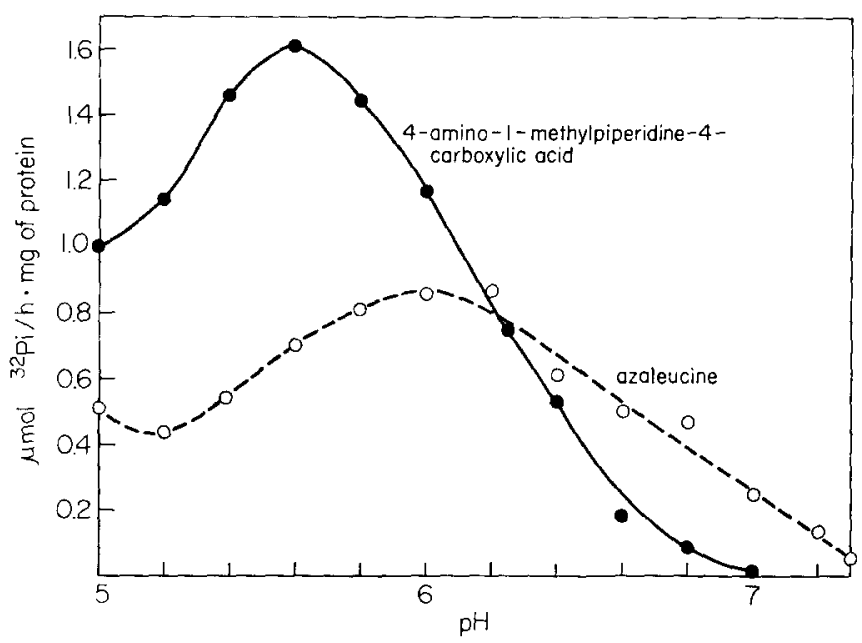

Fig. 2. Effect of $\mathrm{pH}$ on stimulation of ATP cleavage by 4-amino-1-methylpiperidine-4-carboxylic acid and by 1 -azaleucine $(8 \mathrm{mM})$ in $2-(N$-morpholino- $)$-ethanesulfonic acid buffer, first type of membrane preparation.

teristic substrates of Systems $L y^{+}$and $L$ respectively, both of which systems participate in the transport of azaleucine [14]. Similar results are illustrated for the methylpiperidine amino acid in the presence of 2-aminonorbornane-2-carboxylic acid at $4 \mathrm{mM}$, and for L-thialysine in the presence of the same inhibitor at $16 \mathrm{mM}$.

The stimulating effect of 4-amino-1-methylpiperidine-4-carboxylic acid (Fig. 2) was optimum at $\mathrm{pH} 5.6$, half-maximal at $\mathrm{pH}$ 6.2, and negligible at $\mathrm{pH} 7.2$. The action of azaleucine was optimum at $\mathrm{pH} \mathrm{6,} \mathrm{half-maximal} \mathrm{at} \mathrm{pH} 6.8$, and small at $\mathrm{pH}$ 7.3. The effect of thialysine was also decreased by elevating the $\mathrm{pH}$, but a pH of about 7.7 was required roughly to halve the maximal stimulation. The $\mathrm{p} K_{\mathrm{a} 2}$ values of these analogs are $7.2,8.4$, and 8.4 , respectively. These results indicate that the cationic form of the diamino acid needs to be produced for stimulation; but they suggest that these diamino acids may require higher $\left[\mathrm{H}^{+}\right]$for protonation when combined with the membrane preparation than when in free solution. The same conclusion was reached for their transport, although in that case it is the zwitterionic species that is at least initially accepted for transport.

Second preparation. As shown in Fig. 3, certain amino acids show significant stimulation of the ouabain-insensitive ATP-hydrolyzing activity of the second membrane preparation when prepared using a sodium phosphate buffer. L-Ornithine, transported mainly by System $L y^{+}$in the Ehrlich cell [16], shows the most pronounced effect, whereas $\alpha$-aminoisobutyric acid, at $\mathrm{pH} 7.4$ a model substrate for System $A$, has a negligible effect. L-Leucine, 4-amino-1-methylpiperidine-4-carboxylic acid and azaleucine, which are all System $L$ substrates [14], show moderate but significant stimulating effects in the presence of ouabain.

As shown in Fig. 4, diaminopropionic acid, established as mainly a System $A$ substrate [17], shows the same pattern as that shown by $\alpha$-aminoisobutyric acid. The next higher homolog, 2,4-diaminobutyric acid, transported mainly by System $A$, but partially by System $L y^{+}$[16], has a stimulatory effect, approximately one-fourth of 


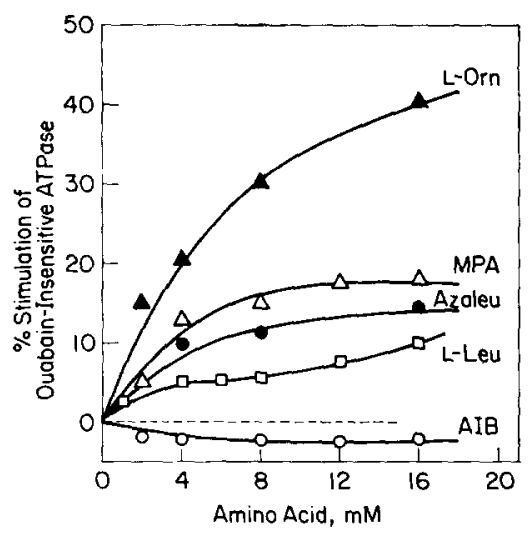

Fig. 3. Effect of various amino acids as a function of concentration on the ouabain-insensitive ATPhydrolyzing activity of the plasma membrane fraction. $\Delta$, L-ornithine; $\Delta$, 4-amino-1-methylpiperidine-4-carboxylic acid (MPA); $\odot$, azaleucine; $\square$, L-leucine; $O, \alpha$-aminoisobutyric acid (AIB). The stock solutions of the amino acids $(120 \mathrm{mM})$ were prepared in $15 \mathrm{mM}$ sodium phosphate and were adjusted to $\mathrm{pH}$ 7.4. Concentrations of amino acid in the incubation medium varied from 1 to $16 \mathrm{mM}$ as indicated in the figure. Incubation was in $15 \mathrm{mM}$ sodium phosphate buffer ( $\mathrm{pH} \mathrm{7.4)}$ at $37^{\circ} \mathrm{C}$. Each point represents the average of at least two experiments with a single batch of the plasma membrane. The stimulation by $16 \mathrm{mM}$ L-ornithine was measured in each batch of the plasma membrane. Then the value was used to standardize the variations of the amino acids actions among different batches of the plasma membrane.

that by L-ornithine. Further increase of the number of carbon atoms in the amino acid structure, however, resulted in the decrease of stimulation, as illustrated by Llysine. In addition, as shown in Fig. 5, stimulation by L-ornithine is about 3 times greater than that by its D-isomer, although no such property was found for the smaller
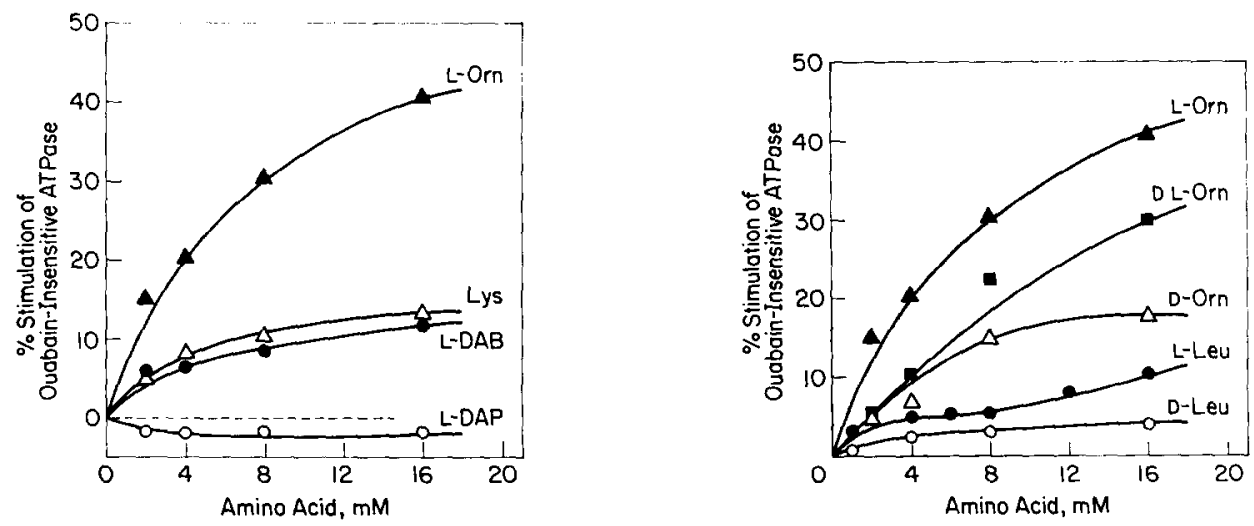

Fig. 4. Plot showing the different actions among the 4 homologs of diamino acids on the ouabaininsensitive ATP-hydrolyzing activity of the plasma membrane fraction. $\boldsymbol{\Delta}$, L-ornithine; $\triangle, D$ or $\mathrm{L}$ lysine; , L-diaminobutyric acid; O, L-diaminopropionic acid. Conditons were the same as in Fig. 3.

Fig. 5. Comparison of the stimulatory actions of D-, L- and DL-ornithine, and D- and L-leucine on the ouabain-insensitive ATP-hydrolyzing activity of the plasma membrane fraction. A, L-ornithine; a, DL-ornithine; $\triangle$, D-ornithine; $\bullet$, L-leucine; $O$, D-leucine. Conditions were the same as in Fig. 3. 

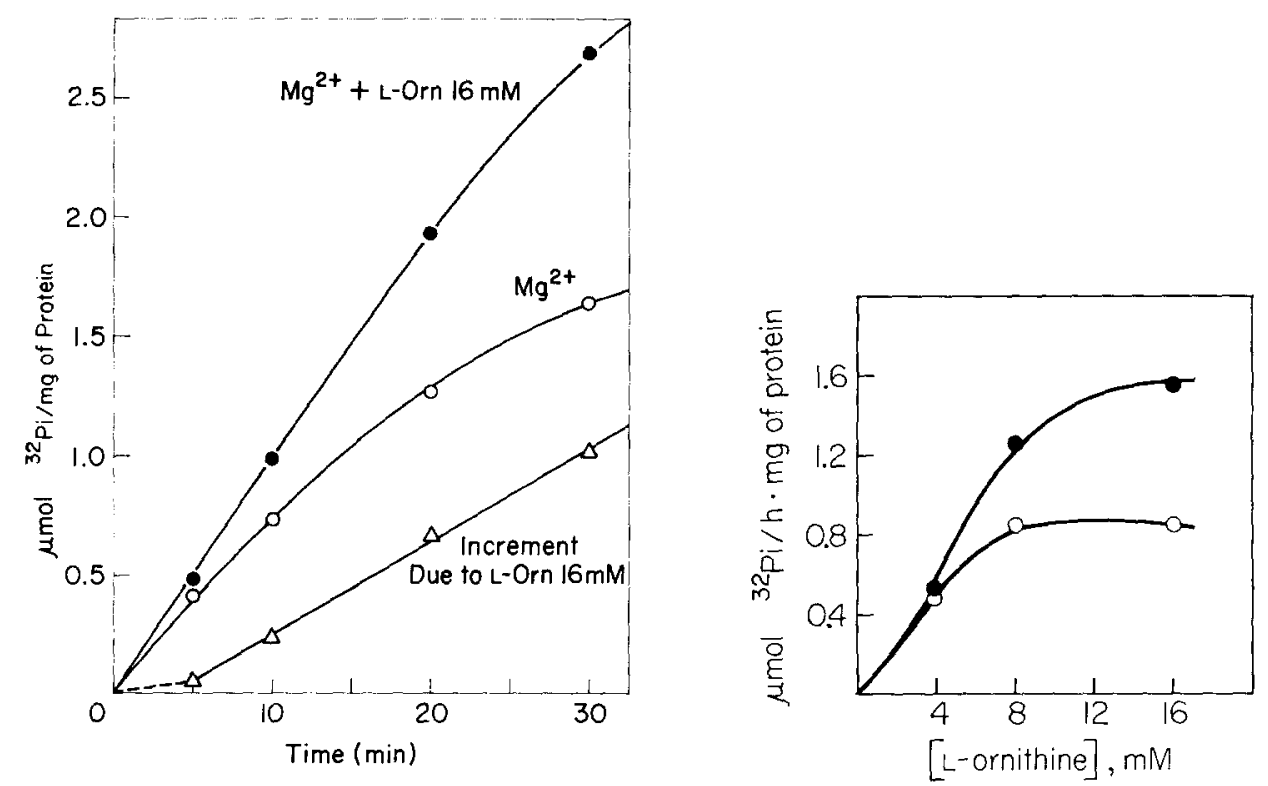

Fig. 6. Time course of the basal ouabain-insensitive ATP-hydrolysis, $(O)$ and the stimulatory action of 16-mM L-ornithine on the activity (O) of the plasma membrane fraction. Increment of ATPhydrolysis due to L-ornithine $(\triangle)$ was computed from the points of the upper two lines.

Fig. 7. Effect of length of the preliminary incubation time of the plasma membrane fraction in the presence of 4, 8 and $16 \mathrm{mM}$ L-ornithine on the net increment of the ouabain-insensitive ATP-hydrolJysis due to the amino acid., $20 \mathrm{~min}$; $O$, zero min.

effect of lysine. A 3:1 difference was observed between $L$ - and D-leucine. The effect of D-ornithine appears to be neither additive to nor competitive with the action of Lornithine on the ouabain-insensitive ATP-hydrolyzing effect. Fig. 6 shows the timecourse of stimulation of the activity of L-ornithine. The basal $\mathrm{Mg}^{2+}$-requiring ATPcleavage was found to deviate considerably from a linear kinetics after an initial 10 min of incubation time. The increased rate due to L-ornithine computed from the two upper lines (with and without L-ornithine), however, shows a time dependence, after an unexplained initial 5-min lag period. Fig. 7 shows that the presence of the Lornithine $20 \mathrm{~min}$ prior to ATP addition enhanced its action. The same effect was obtained using a 10 - or 30 -min interval of prior contact with ornithine.

Although the occurrence of ouabain-insensitive ATP-hydrolyzing activity is not unique to plasma membrane, examination of the fractions obtained by differential centrifugation revealed that the stimulatory effect of L-ornithine is associated only with the fractions containing a significant $\left(\mathrm{Na}^{+}+\mathrm{K}^{+}\right)$-ATPase activity. Furthermore as shown in Table II, the increased activity of $\left(\mathrm{Na}^{+}+\mathrm{K}^{+}\right)$-ATPase in a given fraction is accompanied by an increased sensitivity of the ouabain-insensitive ATP-hydrolyzing activity to L-ornithine.

We have examined effects of the ATPase inhibitors, dicyclohexylcarbodiimide (DCCD) and oligomycin, on the various components of ATP-splitting activities shown by the plasma membrane preparation. The action of these well-known inhibitors of mitochondrial ATPase is of special interest because $\mathrm{Mg}^{2+}$-activated ATPase 
TABLE III

EFFECT OF DICYCLOHEXYLCARBODIIMIDE (DCCD) ON THE VARIOUS COMPONENTS OF ATP-HYDROLYZING ACTIVITY OF THE PLASMA MEMBRANE FRACTION

The stock solution of DCCD was prepared in absolute ethanol. Control flasks received the same amount of ethanol $(10 \mu 1)$. Other details as described under Methods.

\begin{tabular}{llc}
\hline Addition & \multicolumn{2}{l}{$\mu$ mol $\mathrm{P}_{1} / \mathrm{h} / \mathrm{mg}$ of protein } \\
\cline { 2 - 3 } & No inhibitor & $30 \mu \mathrm{M} \mathrm{DCCD}$ \\
\hline $\mathrm{Mg}^{2+}+$ ouabain & 4.0 & 2.6 \\
$\mathrm{Mg}^{2+}+$ ouabain $+\mathrm{MPA}^{\star}, 16 \mathrm{mM}$ & 4.7 & 2.4 \\
$\mathrm{Mg}^{2+}+$ ouabain $+\mathrm{L}$-ornithine, & 6.4 & 2.9 \\
$16 \mathrm{mM}$ & & \\
$\mathrm{Mg}^{2+}+\mathrm{NaCl}+\mathrm{KCl}$ & 14.8 & 12.8 \\
\hline
\end{tabular}

* MPA, 4-amino-1-methylpiperidine-4-carboxylic acid.

activity in purified plasma membrane of yeast has been reported to be insensitive to oligomycin and ouabain, but abolished by water-soluble carbodiimides [18]. As shown in Table III, about $40 \%$ of the ouabain-insensitive ATP-cleavage was inhibited at a $30 \mu \mathrm{M}$ concentration of DCCD. At the same time, the stimulatory effects by Lornithine and 4-amino-1-methylpiperidine-4-carboxylic acid were completely abolished by the presence of the inhibitor, whereas the $\left(\mathrm{Na}^{+}+\mathrm{K}^{+}\right)$-ATPase activity remained unchanged.

Oligomycin decreased by about $40 \%$ the ouabain-insensitive hydrolysis of ATP (Fig. 8). Oligomycin, in contrast to DCCD, did not affect the ATP-splitting activity produced by 4-amino-1-methylpiperidine-4-carboxylic acid or L-ornithine. The action of oligomycin differs from that of DCCD also on the $\left(\mathrm{Na}^{+}+\mathrm{K}^{+}\right)$ATPase activity; here a stepwise decrease of the activity was observed as a function of oligomycin concentration. Note that a considerable portion of the $\mathrm{Mg}^{2+}-\mathrm{ATPase}$ activity in plasma membrane from adipocytes is oligomycin-sensitive and ouabaininsensitive [19]. Therefore the oligomycin-sensitive activity of this membrane preparation is probably not of mitochondrial origin, and the amino-acid-stimulated component is certainly not of that origin.

The ATP-splitting activity due to L-ornithine shows much greater sensitivity toward deoxycholate than does the $\left(\mathrm{Na}^{+}+\mathrm{K}^{+}\right)$-ATPase activity of the ouabaininsensitive ATP-cleavage (Fig. 9); at a concentration of $0.015 \%$ deoxycholate in the medium, $\left(\mathrm{Na}^{+}+\mathrm{K}^{+}\right)$-ATPase activity and the ouabain-insensitive, $\mathrm{Mg}^{2+}$-requiring ATP-hydrolyzing activity reached their highest points, while the magnitude of Lornithine stimulation was reduced to about one-fourth of the initial activity. Therefore a direct interaction between the amino acid and the molecular system for the ouabain-insensitive ATP-hydrolysis is not a plausible basis for the observed effect. Overall, the results agree with a previous report [20] that deoxycholate at appropriately low levels enhances the ATPase activity of plasma membrane. This effect was attributed to an increased fragmentation of the plasma membrane by deoxycholate at low concentrations.

Fig. 10 shows effects of the $\mathrm{pH}$ on the ouabain-insensitive hydrolysis of ATP and on the stimulatory action of amino acids. The ouabain-insensitive cleavage of 
ATP in the absence of added amino acids shows a $\mathrm{pH}$ maximum at 7.8. The optimal $\mathrm{pH}$ for the stimulatory effect of 4-amino-1-methylpiperidine-4-carboxylic acid, in contrast to that with the first membrane preparation, is seen at 7.4. Furthermore, the effects of 4-amino-1-methylpiperidine-4-carboxylic acid and azaleucine were negligible at $\mathrm{pH}$ 6.5, 6.0 and 5.5. For ornithine, the optimum was similar but much broader.
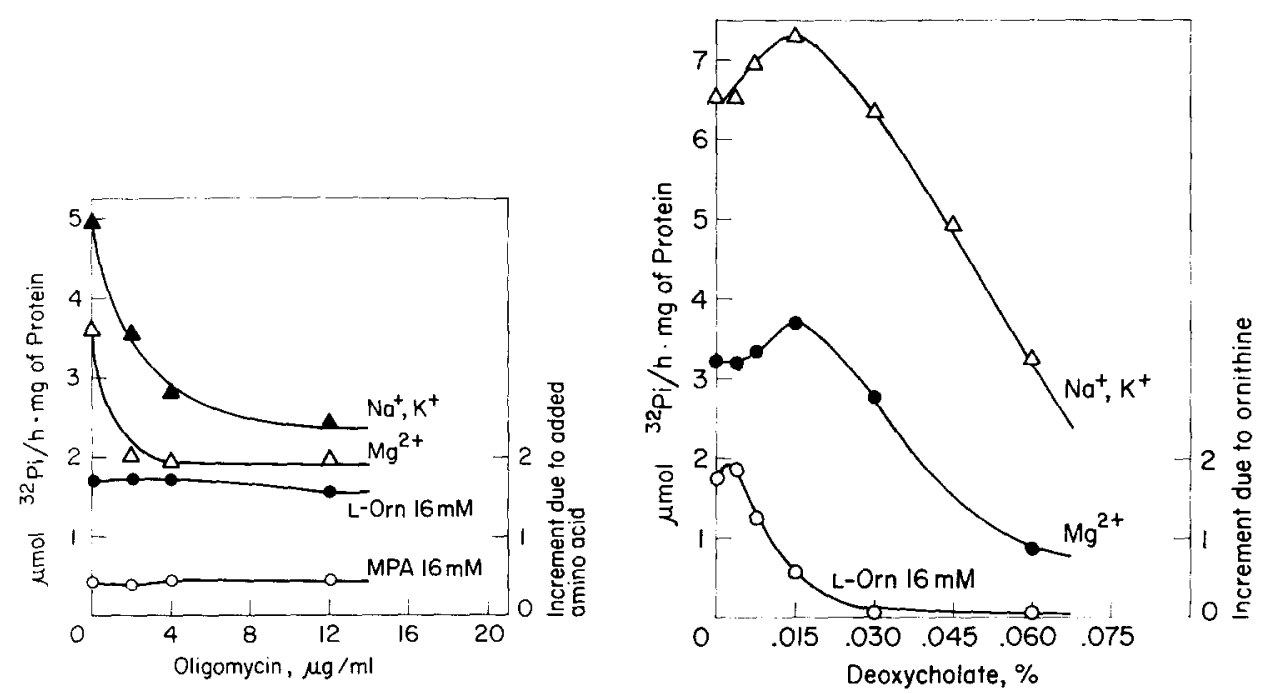

Fig. 8. Effect of oligomycin on $\left(\mathrm{Na}^{+}+\mathrm{K}^{+}\right)$-ATPase activity, ( $\left.\boldsymbol{\Delta}\right)$; the basal ouabain-insensitive ATP-hydrolyzing activity, $(\triangle)$; the stimulatory actions of L-ornithine, $(O)$; and 4-amino-1-methylpiperidine-4-carboxylic acid, $(O)$ on the latter activity of the plasma membrane fraction. Stock solutions of oligomycin were prepared in absolute ethanol. The amount of ethanol (10 $\mu$ l) was kept constant in each flask.

Fig. 9. Effect of varying sodium deoxycholate concentration on $\left(\mathrm{Na}^{+}+\mathrm{K}^{+}\right)$-ATPase activity, $(\Delta)$; the basal ouabain-insensitive ATP-hydrolyzing activity, (O); and the stimulatory action of $16 \mathrm{mM}$ L-ornithine, $(O)$ on the latter activity of the plasma membrane fraction.

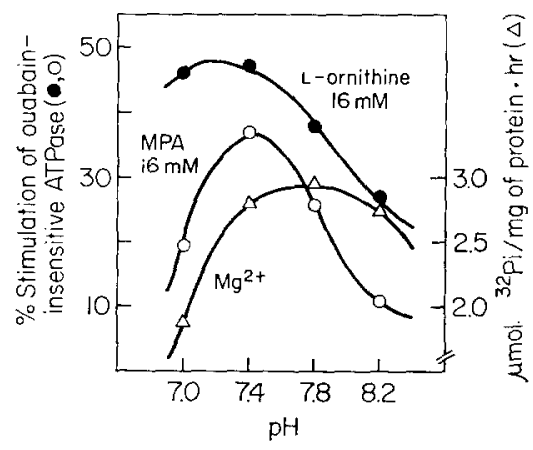

Fig. 10. Effect of pH on the stimulatory actions of L-ornithine (O, scale at the left) and of 4-amino1-methylpiperidine-4-carboxylic acid (O, scale at the left) on the basal ouabain-insensitive ATPhydrolyzing activity ( $\triangle$, scale at the right) of the plasma membrane fraction. The $\mathrm{pH}$ values at the beginning of preliminary incubation were used for plotting. 
TABLE IV

EFFECT OF THE ONE-DAY STORAGE OF THE PLASMA MEMBRANE FRACTION IN $15 \mathrm{mM}$ TRIS BUFFER (pH 8.0) AT - $20{ }^{\circ} \mathrm{C}$ ON ITS ATP-HYDROLYZING ACTIVITY

Incubation was in $15 \mathrm{mM}$ Tris buffer (pH 8.0) in the presence of $10 \mathrm{mM}$ mercaptoethanol. Other conditions were identical to those in the sodium phosphate buffer ( $\mathrm{pH}$ 7.4). See Methods for details. The plasma membrane fraction was prepared using $18 \mathrm{mM}$ Tris buffer ( $\mathrm{pH} 8.0$ ) as described under Methods.

\begin{tabular}{|c|c|c|}
\hline \multirow[t]{2}{*}{ Addition } & \multicolumn{2}{|c|}{$\mu \mathrm{mol} \mathrm{P}_{\mathbf{1}} / \mathrm{h} / \mathrm{mg}$ of protein } \\
\hline & Before storage & $\begin{array}{l}\text { After one-day } \\
\text { storage }\end{array}$ \\
\hline $\mathrm{Mg}^{2}++$ ouabain & 5.5 & 2.8 \\
\hline $\mathrm{Mg}^{2+}+$ ouabain + MPA $^{\star}$ & 5.4 & 4.2 \\
\hline $\mathrm{Mg}^{2+}+\mathrm{NaCl}+\mathrm{KCl}$ & 12.2 & 8.1 \\
\hline
\end{tabular}

* Concentration of 4-amino-1-methylpiperidine-4-carboxylic acid (MPA) was $8 \mathrm{mM}$ in the storage medium. Before storage, addition of 4-amino-1-methylpiperidine-4-carboxylic acid up to 16 $\mathrm{mM}$ did not show any effect on the ouabain-insensitive ATP-hydrolysis by the plasma membrane fraction.

\section{Effect of Tris buffer}

The plasma membrane preparation of Forte et al [4] was prepared and assayed. in Tris buffer, pH 8.0. For comparison, we have examined effects of the plasma membrane fraction prepared in Tris buffer ( $\mathrm{pH} \mathrm{8.0)}$ ), as described under Methods.

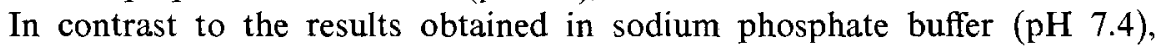
amino acids directly added to the incubation medium failed to give any stimulatory effect with this preparation. This difference is not due to the difference in $\mathrm{pH}$ since even at $\mathrm{pH} 8.0$ in sodium phosphate buffer, 4-amino-1-methylpiperidine-4-carboxylic acid and L-ornithine show significant stimulation of the ouabain-insensitive ATPase activity.

When this membrane fraction prepared in Tris buffer, was stored in $15 \mathrm{mM}$ Tris buffer $(\mathrm{pH} 8.0)$ at $-20^{\circ} \mathrm{C}$, marked decreases of the ouabain-insensitive ATPhydrolyzing activity and $\left(\mathrm{Na}^{+}+\mathrm{K}^{+}\right)$-ATPase activity were observed. As shown in Table IV, after one-day storage the basal ouabain-insensitive ATP-hydrolyzing activity had fallen to only half that measured immediately after the preparation of the membrane fraction. The presence of any of a number of amino acids, all of which are System $L$ substrates, however, could partially protect the ouabain-insensitive ATP-splitting activity, as illustrated here for 4-amino-1-methylpiperidine-4-carboxylic acid. Maximal protection was observed at a concentration of $8 \mathrm{mM}$ 4-amino-1methylpiperidine-4-carboxylic acid in the storage medium.

\section{DISCUSSION}

For a membrane preparation described previously [5], the present experiments have independently verified the stimulating effects on ATP hydrolysis of several diamino acids strongly accumulated by System $L$ in the Ehrlich cell, and indicate that the terminal phosphoryl group is the one released from ATP. The results indicate, however, that the stimulating effect is not produced by occupation of the receptor site 
kinetically described by ordinary studies of System $L$, nor by occupation of the ordinarily observed receptor site for the cationic amino acids, that of System $\mathrm{Ly}^{+}$. The $\mathrm{pH}$ effects indicate that the cationic form of the amino acid is effective, although it is not necessarily the form exclusively required for the effect.

A hypothesis has been discussed elsewhere (ref. 23; see also refs. 14, 21, 22) which calls for each of these diamino acids to assume temporarily its protonated, cationic form at an intermediate stage of its transport via System $L$. The stimulation of ATP cleavage could be produced by occupation of a proposed site ordinarily internal to the membrane, specifically recognizing the cationic form of the amino acid.

The question may well be asked if the effective site producing the stimulation with this preparation is actually associated with the plasma membrane, since the membrane fraction isolated by the method of Ronquist and Christensen [5] shows negligible $\left(\mathrm{Na}^{+}+\mathrm{K}^{+}\right)$-ATPase activity. This enzyme activity is widely accepted as a marker for the plasma membrane. On sucrose density sedimentation under the conditions described by Forte et al. [4] a major band of our first preparation took a position at the same interface as that assumed by their $\left(\mathrm{Na}^{+}+\mathrm{K}^{+}\right)$-ATPase-rich preparation. Our interpretation at this early point was that the deoxycholate treatment had probably destroyed the $\left(\mathrm{Na}^{+}+\mathrm{K}^{+}\right)$-ATPase in this preparation.

The stimulatory action of certain amino acids on the ATPase activity of the second membrane preparation can in some respects be correlated with their transport character istics. The stimulus by 4-amino-1-methylpiperidine-4-carboxylic acid corresponds to its transport by System $L$. The $\mathrm{pH}$ sensitivity of its action on the ATPase in this case resembles the $\mathrm{pH}$ sensitivity of its transport. Diaminopropionic acid produces a hydrolytic response different from that of its higher homologs (Fig. 2), in correspondence to its transport by a different system $(A)$. The somewhat higher stimulus provided by $\mathrm{L}$ isomers of certain amino acids corresponds to the incomplete stereospecificity of their transport.

Furthermore, the component of ATPase activity obtained on amino acid addition can be differentiated from the background $\mathrm{Mg}^{2+}$-ATPase activity by the high sensitivity of the former to deoxycholate action.

For the first membrane preparation, the three amino acids showing unusually steep accumulation attributed to System $L$ are all strong stimulators of ATP cleavage in the presence of ouabain. Results with other substrates of the same transport system indicate, however, that this effect has an origin other than through entry into the kinetically described receptor site for that system. The stimulation of ATP cleavage by the second preparation is produced, apparently independently, by substrates of two $\mathrm{Na}^{+}$-independent transport systems, but only by some substrates of these systems. Questions that may contribute to these paradoxes concern modified access, possibly even modified shape, of effector sites during membrane preparation; also of the apparently variable access of analogous substrates of a given transport system to the energizing events associated with the operation of that system. We are accordingly not able at this point to establish or exclude a close relation of these effects of amino acids on ATP cleavage to their transport.

\section{ACKNOWLEDGEMENTS}

The experiments deriving from this laboratory received support through a grant (HD01233) from The National Institute of Child Health and Human Develop- 
ment, National Institutes of Health, United States Public Health Service. B.S. was on leave from medical studies at the University of Paris.

\section{REFERENCES}

1 Skou, J. C. (1964) Prog. Biophys. Biophys. Chem. 14, 131-166

2 Ting-Beall, H. P. and Wells, W. W. (1971) FEBS Lett. 16, 352-354

3 Specht, S. C. and Robinson, J. D. (1973) Arch. Biochem. Biophys. 154, 314-323

4 Forte, J. G., Forte, T. M. and Heinz, E. (1973) Biochim. Biophys. Acta 298, 827-841

5 Ronquist, G. and Christensen, H. N. (1973) Biochim. Biophys. Acta 323, 337-341

6 Glynn, I. M. and Chappell, J. B. (1964) Biochem. J. 90, 147-149

7 Lindberg, O. and Ernster, L. (1955) Methods Biochem. Anal. 3, 1-22

8 Lindberg, O., Ernster, L. and Zetterström, R. (1950) Acta Chem. Scand. 4, 942-947

9 Lindberg, O., Ernster, L. and Zetterström, R. (1952) Acta Chem. Scand. 6, 804-805

10 Berenblum, I. and Chain, E. (1938) Biochem. J. 32, 295-298

11 Martin, J. and Doty, D. (1949) Anal. Chem. 21, 965-967

12 Lowry, O. H., Rosebrough, N. J., Farr, A. L. and Randall, R. J. (1951) J. Biol. Chem. 193, 265275

13 Blostein, R. (1968) J. Biol. Chem. 243, 1957-1965

14 Christensen, H. N. (1973) J. Bioenerg. 4, 231-261

15 Steck, T. L. (1972) in Membrane Isolation in Membrane Molecular Biology (Fox, C. F. and Keith, A. D., eds.), pp. 76-114, Sinauer Associates Inc., Stamford, Conn.

16 Christensen, H. N. and Liang, M. (1966) J. Biol. Chem. 241, 5542-5551

17 Christensen, H. N. (1964) Proc. Natl. Acad. Sci. U.S. 51, 337-344

18 Furhmann, G. F., Wehrli, E. and Boehm, C. (1974) Biochim. Biophys. Acta 363, 295-310

19 Jarett, L. and Smith, R. M. (1974) J. Biol. Chem. 249, 5195-5199

20 Philippot, J. and Authier, M. H. (1973) Biochim. Biophys. Acta 298, 887-900

21 Christensen, H. N., de Cespedes, C., Handlogten, M. E. and Ronquist, G. (1973) Biochim. Biophys. Acta $300,487-522$

22 Christensen, H. N. (1974) Ann. N.Y. Acad. Sci. 227, 355-379

23 Christensen, H. N. and Handlogten, M. E. (1975) Proc. Natl. Acad. Sci. U.S. 72, 23-27 